\title{
SEEING THE COLORS OF RAINBOWS Affective Politics of Queer Belonging
}

Tuula Juvonen and Marjo Kolehmainen

Within the past few years, the debate concerning the status of same-sex marriage and other human rights questions has been intense in the western world. Finland is no exception, as the Parliament approved the bill for gender-neutral marriage law, including the right to adopt, in 2014. The heated debates about couplehood and kinship preceding the approval of the new law show the affective importance of politics of belonging (Juvonen 2015). Despite, or because of its affective dimensions, the concept of 'belonging' itself has rarely been questioned, as the arguments rather concern where and when the boundaries of inclusion/exclusion should be drawn. For example, although the gender-neutral marriage law came into effect in Finland, the struggle for belonging continues, as equal access to church weddings is now being fought for.

Whereas many view legal changes of this kind as welcome improvements that make a society equal, the increasing assimilation of sexual minorities - especially lesbians and gays - has also been criticized for its homonormativity. This entails accusations of the reproduction of such couple-normativity, which fails to acknowledge social bonds beyond the ideal of a dyad. Such a critique of marriage and other assimilationist goals demonstrates that the idea(l) of belonging can be 'queered. Hence, it can be argued that one of the strengths of queer studies lies in the fact that it offers a means to expand discussion about belonging to wider questions of inclusion and exclusion, not restricted to the familial notions of gay rights discourses only.

Within the Finnish queer community the question of belonging is evident in the use of shifting acronyms. The previously commonly used LGBT has now been replaced with LGBTI, and many have recently started to use the acronym LGBTIQA+, where the plus signals an attempt at further inclusion. However, it remains to be seen to what extent 'belonging' itself can be queered, and what that could do for queer politics and studies. Almost without exception belonging is appreciated as a positive thing, and as something to aspire towards (Lähdesmäki et al. 2016). However, the intersections of affect theory and queer theory have proven successful in troubling the dualism of assimilation and abjection, which, in turn, has provided possibilities for a critical exploration of non-belonging (Liu 2017). 
This $10^{\text {th }}$ anniversary issue of SQS - Journal of Queer Studies in Finland reminds readers that within queer studies 'belonging' is relevant to phenomena much wider than the relations between 'normative heterosexuality' and 'non-normative sexualities.' While it is surely crucial to consider such sites of inequality as marriage laws and adoption rights, these familist discourses and policies often overshadow the topic of communality - which reaches well beyond the most easily recognized and valued forms of social bonding, such as couple relationships or reproductive families. Moreover, this issue hopes to bring forward how affective dimensions of belonging are omnipresent when studying the desire for attachments (Lähdesmäki et al. 2016). Exploring affectivity provides a fruitful tool for identifying belonging and non-belonging, and related inequalities and asymmetries. While affects mark a body's belonging as well as non-belonging to the world, they not only draw us together, whatever our intentions; they also force us apart, or signal the lack of any real intersubjective connection (Hemmings 2012; Seigworth and Gregg 2010). In this issue, several texts highlight communal forms of affective belonging, well beyond any formal recognition.

\section{Intersectional inclusions and exclusions}

Belonging is not only about the relation between, but also within social groups. Hence, inclusions and exclusions not only take place when gay rights are debated; but, rather, also within the queer community, and between queer communities. The articles and other texts published in this issue all point to the ways in which politics of belonging always entail wider power relations. Even though not necessarily explicitly employing the concept of 'intersectionality', several texts provide insights into how the sense of belonging, as well as the politics of belonging, are shaped along multiple axes of difference - such as gender, sexuality, race, class and religion. The term 'intersectionality' was first introduced by Kimberlé Crenshaw (1989), who examined how both feminist and anti-racist discourse in the US failed to take into account the experiences of those women who were positioned simultaneously as women and black. An intersectional approach that considers the simultaneous positionalities allows us to multiply our notions of sexual norms, as they are often (re) structured around intersecting social categories (see Kolehmainen 2012). Similarly, the idea of a queer community is problematized when the axes of multiple difference are taken into account.

'Rainbows include the whole spectrum of different colours, but how many colours we distinguish depends on our specific social and linguistic milieu', Nira Yuval-Davis (1996) explains when writing about intersectionality. In this issue, the texts published discuss e.g. the axes of sexuality, gender, race, class, religion, and generation. In his book review of Jin Haritaworn's Queer Lovers and Hateful Others. Regenerating Violent Times and Places Luca Tainio stresses Haritaworn's argument that 'queers' are not a unified group. Although social categories such as gender, sexuality or ethnicity not only count for the 'Others' but also shape the experiences of the privileged and the powerful (Staunaes 2003), Haritaworn - in their analysis of gentrification processes in Berlin and the ensuing categories of 'good' and 'bad' queers - argues that the queers that are seen as the most desirable ones are usually white, middle-class, young and able. In this way, the white and desirable queer figure flourishes at the expense of the racialized others.

As Bessie Dernikos in her opinion piece demonstrates, it is not selfevident that the queers will find their place easily among the racialized others either. In the US, three black women founded \#BlackLivesMatter in 2013 as a response to the acquittal of the shooter of a black man, Trayvon Martin. Since then \#BLM has developed into a wide sociopolitical

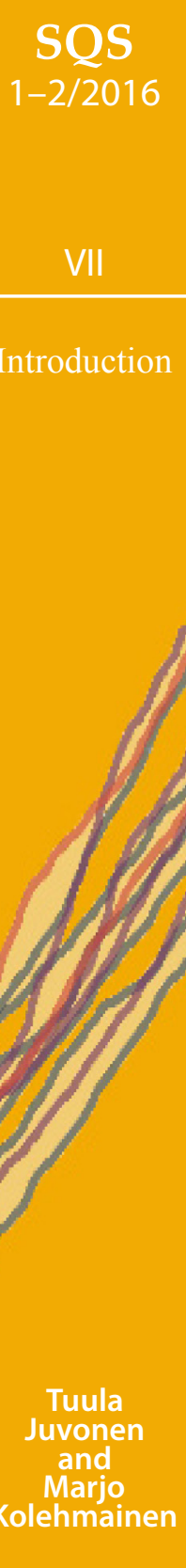


movement as its affective activism continues to bind strangers together into a collective. Yet simultaneously the very same affects intensified internal divisions along the social categories of race, gender and sexuality. In the end, queer identities and bodies - including those of the founding members - have become erased from the movement in a manner that disrupts the initial intention of \#BLM to argue that all black lives matter. Dernikos thus suggests that turning to affect will help us better understand the complex ways that bodies come to matter, or not, within public spheres.

The simultaneous belonging to two communities that are often considered mutually exclusive is also a topic that Eetu Kejonen and Teemu Ratinen explore when analysing the affective ambivalences and tensions of lesbian and gay identified people who are or who have been members of the Finnish religious community of Conservative Laestadianism. Their article demonstrates how affect theory offers a fruitful tool to explore the overwrought dynamics between and within different social groups. In this case, one group is strongly committed to the idea of a heterosexually reproductive nuclear family, and another poses a challenge to it. Especially when affect as a concept is not reduced to individual response, new possibilities for deepening our understanding of the politics of belonging open up.

\section{Creating belonging through spatiality and materiality}

As queer history demonstrates, often the intentional creation of communal spaces is required to establish a community and to generate a sense of belonging. In particular, human geography, with its interest in spatiality and sexuality, has been vital in advancing queer and feminist research on communities (Knopp 2007; Browne and Ferreira 2015; Brown and Browne 2016). Even though work on spatiality and affect is still rare, openings have been made, e.g. in discussions concerning atmospheres
(Anderson 2009). Likewise, the intersection of materiality and affectivity is about to propel new research among queer theorists. In this special issue, the authors begin to raise such issues in the context of queer belonging.

Professor in Communication and Performance Studies Elizabeth Whitney from the U.S., who visited Finland as a Fulbright scholar, explores in her autoethnographical essay the limits and possibilities of belonging to a queer community with which she did not share the same spoken language. What were the affective moments that could bridge a cultural divide and thus create a feeling of queer belonging? In her quest for queer world making in public queer communities, Whitney was guided by her affective pleasure in recognizing (un)familiarity in ways of being and acting at queer feminist events and venues.

Likewise, ethnologist Johanna Pohtinen analyses belonging in a chosen community in her article. Pohtinen analyses the modes of affective belonging in the oral and written narrations of those people who have found the on-line fora and especially the off-line events organised by Finnish BDSM and fetish organisations. Pohtinen sees the events as affective zones that require work to exist, work that involves active participation both from the organizers and the guests. The sociability at the events is largely facilitated in material ways. In addition to the crucial role of etiquette, the article points out the importance of clothing, emblems and BDSM equipment for creating an atmosphere of solidarity in which the feeling of belonging becomes possible, and where the principles of safe space may come true.

The German historian Benno Gammerl takes such material-affective analysis further, combining it with temporality. In his opinion piece, Gammerl discusses the intertwined roles of affect and spatiality in establishing gay men's communities in Germany. In his careful analysis of oral history interviews with gay men, Gammerl is able to show how the 
spatial arrangements of gay venues, a gay bar of the 1960s, and a disco of the 1980s, respectively, offer very different settings for creating affective bonds between men. He bases his analysis on various theoretical approaches, and suggests how fruitful such a theoretical plurality can be when trying to get hold of the affectivity of material spaces.

\section{Temporal belongings}

Affective belonging is, of course, thoroughly contextual. The book review of Heidi Kurvinen on a fellow historian Sandra Hagman's monography Seitsemän outoa veljestä traces the modes of antagonistic non-belonging of homosexuality in the Finnish culture and society from the early $20^{\text {th }}$ century to the present day. Hagman's book is based on her previous dissertation Seven queer brothers: narratives of forbidden male same-sex desires from modernizing Finland 1894-1971, where the files of select court cases have been analysed. Kurvinen points out how Hagman in her micro historical case studies succeeds in identifying, for example, how the cultural perception of male homosexuality has shifted from a relatively irrelevant (mutual) masturbation activity in the agrarian Finland to a thoroughly medicalized phenomenon by the 1930s. By the time Finland was to host its first Olympic Games in 1952, male homosexuality had become an affectively highly invested criminal offence. Even after the decriminalisation of homosexual deeds in 1971, homosexuality remained a heavily contested topic in public debates in Finland.

Especially in times when homosexuals have been the outcasts of society, cultural products have been crucial in queer world making, as places to imagine differently. The cultural historian Heta Mulari reviews the monography Muutoksen musiikki. Pervoja ja ekologisia utopioita audiovisuaalisessa kulttuurissa [The Music of Transformation: Queer and Ecological Utopias in Contemporary Audiovisual Culture], written by the musicologist Susanna Välimäki. Välimäki analyses the many ways in which art can challenge and transform our thinking by initiating utopic moments. Such artwork can travel to Finland from elsewhere, quite as Stephen Daldry's film Hours did, or emerge in local settings. As Mulari highlights, learning to identify artworks' utopic spaces is particularly important for queers, who may be neither willing nor able to relate with affective belonging to the hegemonic cultural structures.

We are pleased to conclude that the $10^{\text {th }}$ anniversary issue of $S Q S$ - Journal of Queer Studies in Finland has managed to bring together authors from a variety of social and linguistic milieus, from Finland and elsewhere. By furthering the discussions on queer theory, affect theory, and studies on belonging, the authors are helping, in Yuval-Davis's (1996) words, to distinguish more colours in the spectrum of a rainbow. The colours of rainbows are also present in the cover image. We would like to thank photographer Mari Hokkanen for the permission to use the artwork Operation Gay Over (2014) from the narrative series Set and Settings as the cover photo.

At this point we, as the editors in chief, are also happy to hand over the journal to our colleagues at the University of Turku and Åbo Akademi, who are already putting together the upcoming special issues Queer Healings and Queer bioethics and biopolitics for the year 2017. As the Society for Queer Studies in Finland has been able to secure funding for the first time in 10 years from both the Federation of Finnish Learned Societies and the Ministry of Education and Culture for the publication of its journal $S Q S$ - for which we express our gratitude-, we look forward to increasing possibilities to engage with and further queer scholarship on the pages of SQS.

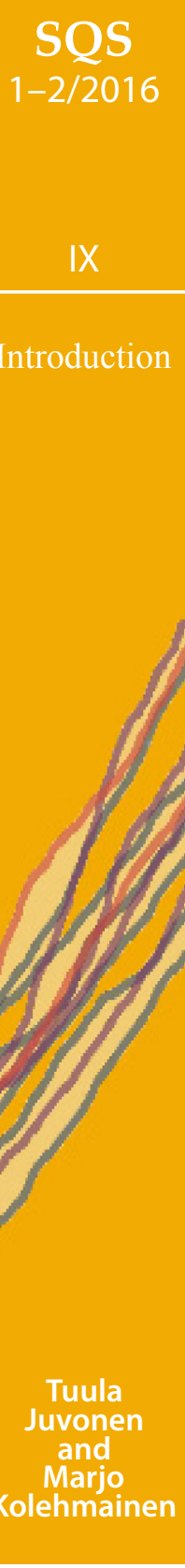




\section{References}

Anderson, Ben. 2009. "Affective Atmospheres." Emotion, Space and Society 2(2009): 77-81. https://doi.org/10.1016/j.emospa.2009.08.005

Brown, Gavin, and Kath Browne (eds.). 2016. Routledge Research Companion to Geographies of Sex and Sexualities. London: Routledge.

Browne, Kath, and Eduarda Ferreira (eds.). 2015. Lesbian Geographies. Gender, Place and Power. London: Routledge.

Crenshaw, Kimberlé. 1989. "Demarginalizing the intersection of race and sex: A black feminist critique of antidiscrimination doctrine, feminist theory and antiracist politics." University of Chicago Legal Forum 14: 538-554.

Hemmings, Clare. 2012. "Affective solidarity. Feminist reflexivity and political transformation." Feminist Theory 13(2): 147-161. https://doi. org/10.1177/1464700112442643

Juvonen, Tuula. 2015. Kaapista kaapin päälle. Homoseksuaaliset ihmisetja heidän oikeutensa edustuksellisessa politiikassa [Out and Elected. Homosexual people and their rights in parliamentary politics]. Vastapaino: Tampere.

Knopp, Larry. 2007. "On the Relationship Between Queer and Feminist Geographies." The Professional Geographer 59(1): 47-55. https://oi. org/10.1111/j.1467-9272.2007.00590.x

Kolehmainen, Marjo. 2012. "Tracing ambivalent norms of sexuality: Agony columns, audience responses and parody." Sexualities 15(8): 978-994 https://doi.org/10.1177/1363460712436822

Liu, Wen. 2017. "Toward a queer psychology of affect: restarting from shameful places." Subjectivity 10(1): 44-62 (prepublished). https://doi.org/10.1057/ s41286-016-0014-6

Lähdesmäki, Tuuli, Tuija Saresma, Kaisa Hiltunen, Saara Jäntti, Nina Sääskilahti, Antti Vallius, and Kaisa Ahvenjärvi. 2016. "Fluidity and exibility of 'belonging': Uses of the concept in contemporary research." Acta Sociologica 59(3): 233-247. https://doi.org/10.1177/0001699316633099

Seigworth, Gregory J., and Melissa Gregg. 2010. “An inventory of shimmers.” In Affect Theory Reader, edited by Gregory J. Seigworth and Melissa Gregg. Durham and London: Duke University Press.

Staunaes, Dorthe. 2003. "Where have all the subjects gone? Bringing together the concepts of intersectionality and subjecti cation." NORA 11(2): 101-110. https://doi.org/10.1080/08038740310002950

Yuval-Davis, Nira. 1996. "Belonging and the politics of belonging." Patterns of Prejudice 40(3): 197-214. https://doi.org/10.1080/0031322060076933 